HALMOS KÁROLY

\title{
ZSIDÓK ÉS ZSIDÓSÁG NEVES TÖRTÉNÉSZEK 1945 ELŐTTI MUNKÁIBAN ${ }^{1}$
}

DOI: $10.18030 /$ socio.hu.2015.2.24

\section{ABSZTRAKT}

Egy elfogadott eszmetörténeti közelítési mód szerint az eszmék az őket hordozó nyelven keresztül hatnak, létrehozzák szótárukat, hatásukat az általuk megteremtett nyelvezeten keresztül fejtik ki. Az eszmék közötti vita és csere is e nyelvi eszközök segítségével zajlik. Amit megkísérlek, az néhány példa bemutatása, hogy a (kinél-kinél igen különböző mértékű) antiszemita beszédmód mögött milyen eszmék húzódhattak meg a korabeli történészek körében. Példaként a céhbeliek közül Szekfü Gyulát, Mályusz Elemért, Hajnal Istvánt, esetleg Farkas Gyulát, illetve Szabó Istvánt hozom, és a sort kiegészítem két nagyhatású, de nem céhbeli történetíróval, Erdei Ferenccel és Bibó Istvánnal.

Kulcsszavak: világháborúk közötti kor historiográfiája

\section{ABSTRACT}

Károly Halmos: Jews and Jewry in Distinguished Historians' pre-1945 Works

As one of the recognized approaches of the history of ideas suggests ideas are constituted and conveyed through verbal language. Debates and exchange among ideas also take place through language. In this paper I attempt to introduce some of the ideas that underlined (to different extents) the anti-Semitic discourse of historians. For example I will explore Gyula Szekfú, Elemér Mályusz, István Hajnal, maybe include Gyula Farkas and István Szabó, and will complete the list with two significant thinkers Ferenc Erdei and István Bibó.

Keywords: interwar Hungarian historiography

Ez az írás felkérés alapján, egy konferencia-előadásból született. A tanácskozás szervezői azt a kérdést tették föl, miképp és milyen mértékben vált részévé a nemzetiszocialista szellem és a faji politika a két világháború közötti egyetemi és akadémiai életnek, hogyan és milyen mértékben alakította a korabeli társadalomtudományi gondolkodást és kutatásokat, és milyen hatást gyakorolt a szellemi múhelyekre. Arra is kíváncsiak voltak, milyen ideológiai szerepet töltöttek be a korban a korszak uralkodó társadalomtudományos és áltudományos irányzatai.

Magam e célkitúzésekhez csak kevéssé tudok hozzájárulni. Bár vállalkozástörténeti kutatásaim során gyakran merültek fel zsidókra és a vállalkozók zsidóságára vonatkozó kérdések, de a zsidótörvényekkel, 
náci fajelmélettel nem foglalkoztam. Sőt, a kutatások során - tartván attól, hogy a szellemiségre vonatkozó előföltevések mintegy előítéletekként kezdenének viselkedni - a tekintetem elé került zsidó, vagy zsidó származású vállalkozók nagy száma ellenére kifejezetten kerültem a zsidóság (e szó jelentésének változásáról később még szó esik), a zsidó szellem magyarázó tényezőként való használatát. Hogy ennek ellenére a konferencia szervezőinek látókörébe kerülhettem, az lehet az oka, hogy ugyanezen kutatások fogalomtörténeti problémái egészen a historiográfia tanulmányozásáig vezettek.²

E magam mentsége mellett viszont szóvá is szeretném tenni pár gondomat. Az utóbbi idők vitái - gondoljunk itt akár a nemrégiben zajlott, akár a mostanában zajló vitára - csak megerősítik, hogy a szakmai és a közéleti viták során a résztvevők nem megfelelően tisztázott jelentésű fogalmakkal élnek. Az „antiszemita” és vele rokon kifejezések parttalanok, a történészek nem fordítanak kellő figyelmet a tárgykorszak és az elbeszélői jelen közötti terminusok elhatárolására, a két idősík nyelve közötti „fordításra”.

Gerő Andrásnak és vitapartnereinek nemrég lezajlott, Romsics Ignác történetírásáról folytatott eszmecseréje egyrészt új szempontokat adott az antiszemitizmus hazai elemzéséhez, másrészt továbbra is fenntartotta a kifejezés homályosságát. Az új szempont az antiszemita habitus és az antiszemita nyelvi pragmatika megkülönböztetése volt. A kifejezés homályossága azonban evvel még tovább mélyült - nehéz volna olyan tesztet találni, aminek alapján egy kívülálló eldöntheti, vajon egy adott közlés antiszemita-e vagy sem. Korábban az antiszemitizmus kérdése úgy merült föl, hogy vannak kifejezetten - bármit értsünk is e megnevezés alatt - antiszemita megnyilvánulások, illetve e megnyilvánulásoknak van egy leplezett formája. Ez utóbbit kódolt beszéd néven is emlegetik. A „ki az antiszemita” kérdés a kifejezett megnyilvánulás esetében egyértelmúnek volt mondható: az, aki megnyilvánult. A leplezett eset bonyolultabb. Ez az értelmezés sajátos kommunikációs föltevéssel él. Volna egy mondanivalóját (a közvélemény nyomása miatt) elrejtő, tehát gyáva vagy megalkuvó (mondhatnók: morális integritását feladó) közlő. Volna a közlést váró és desifrírozni tudó, a közlővel egy húron pendülő közönség. Végül, és harmadik félként (esetleg akár többen) még volna, aki ugyancsak képes a közlést dekódolni, azaz leleplezni, de a közlési folyamat résztvevőinek szándékaiban legalábbis nem osztozik. Ezekhez a korábbi értelmezési mintákhoz járult a viták során a nem szándékos antiszemita megnyilvánulás mintája - tehát annak elvi lehetősége, hogy valaki nem vall antiszemita nézeteket, de közlendője mégis antiszemita kliséket tartalmaz.

Ezt a jelentéstani elmosódottságot kihasználom, és szemantikai rekonstrukció helyett egyszerúen személyes értelmezést adok e kifejezéseknek - értelemszerűen tudomásul véve, hogy azokat, akik nem fogadják el szóhasználatomat, mint olvasóközönséget elveszítem. A szemantikai zavarnak még egy következményével kell szembenézni. Az antiszemitizmus a néha meglehetősen személyessé vált vitákban (néhol már inkább veszekedésekben) ultima ratio-ként, valaki személyes erkölcsi integritását kikezdő vádként is megjelent. Aki e témában megszólal, evvel a veszéllyel számolnia kell.

Magam részéről az antiszemitizmus kifejezést két értelemben fogom használni. Egyrészt mintegy gyorsírási jelként azokra az esetekre, amikor a zsidó(ság) kifejezés negatív összefüggésben szerepel. Másrészt a politikai „izmusok” értelmében, tehát a politikai aktivitás (ami lehet beszédaktus is) végső vezérlő elveként. A 
„zsidóság” kapcsán megjegyzendőnek tartom, hogy e kifejezést a köznyelv - miként például a jobbágyságét is - ma jobbára individuumok halmazának, régiesen szólva társadalmi csoportozatnak a megjelölésére használja. Az efféle elvont kifejezéseket még a 19. században is szellemre, illetve intézményekre vonatkoztatták. Például Acsády Ignácnak (1944) a jobbágyság történetéről írt munkája nem a jobbágysorú emberekről, hanem a jobbágyságot alakító jogról szól. De hat évtizeddel korábban, Karl Marx (1957) is ilyen értelemben, szellemi mintázatként írt a zsidóságról a kérdésről szóló munkájában. ${ }^{3}$ Ez a jelentés nem veszett ki, de a szociologizáló értelmezés kétségtelenül fölébe kerekedett. A marxi fogalomhasználat egyben mutatja ezen értelmezés ellentmondásosságát: a szellemiség elszakítása attól, amit ma identitásnak nevezünk, szélsőséges esetben azt is jelentheti, hogy a zsidóság mint jellemvonás - a marxi ellentétpárokat használva - csak és kizárólag keresztyén ${ }^{4}$ felekezetekhez tartozó, és még csak nem is zsidó származású személyeken mutatkozik meg.

A zsidóellenesség értelmezésemben kifejezetten igényt tart arra, hogy zsidó egyéneket azonosítson, és azoknak a kárára valamit tegyen. Szabó Miklós hajdani bon mot-ját parafrazeálva az antiszemitizmushoz valóban nem kellenek zsidók - a zsidóellenességhez nagyon is.

A fajvédelem kifejezést egy olyan viselkedésmódra használom, melynek célja a faji tisztaság megőrzése. ${ }^{5}$ A faj kifejezésnek nem kell vér szerinti, genetikai fajiságot jelentenie, a korabeli szóhasználat sokkal inkább a kultúra nem tudatosított részére (anyanyelv, metakommunikációs szokások, életviteli-termelési hagyományok) vonatkozik. A fajvédelemnek, ha politikai irányzat, nem vezérlő elve, hanem eszköze a zsidóellenesség. Ismét csak tekintélyi hivatkozással élve, egyszer Bence György mondta, hogy az antiszemitákat az „igazi” zsidók, míg a fajvédőket az „asszimilált” zsidók irritálják.

Bár a faj fogalmának használata a két háború között általános, akkor már nem volt új - a dualizmus idején ma szabadelvűeknek tekintett közírók, történészek (pl. Beksics Gusztáv, Kállay Béni) használták. ${ }^{6}$ Beksicsnél (Censor 2005:89-92) a faj védelme a középosztály védelmét jelentette. A megváltozó szóhasználat a nép fajiságát fogalmazza meg, legjobb példa erre Szabó Dezső (1989). Szekfú Gyula (1922a) a Faji sajátosságaink a gazdaságtörténet világánál (különlenyomatként már: A magyar bortermelő lelki alkata) c. esszéjében (Szekfú 2002) megkísérel egy középosztály-kritikus, néplélektani, de nem népi fajiságról beszélni. A fajiság kategoriális jelentőségű a népiségtörténet esetében - a történészek általában a kultúra öntudatlan komponenseként fogalmazták meg.

A fajvédő nézetet képviselők germanofóbok is lehettek, sőt adott esetben ez a fóbia fölülírhatta antiszemita érzületüket, amiként ez az ország német megszállása idején esetenként meg is történt. A fajvédőhoz hasonló képlet megtalálható a közéleti katolicizmus egyes irányaiban is (például: Magyar Kultúra folyóirat), ahol az antiszemita megnyilvánulások együtt jelentek meg az egyéb keresztény felekezetek elleni kirohanásokkal, és a következetes nemzetiszocialista-ellenességgel - ez utóbbit a nácizmus pogánysága és keresztényellenessége váltotta ki.

3 Az évszámok a hivatkozott megjelenésekre vonatkoznak. Az eredeti megjelenés évszáma a címleírásban található.

4 Karl Marx születésétől fogva a lutheránus felekezet - a porosz államegyház - tagja volt.

5 Külön mintázatként való kezelését I. Lengyel 1991.

6 Ez a szociáldarwinizmus hatása miatt nem lehet meglepő. V.ö. Takáts (1996).

7 Megjelent 1913-1944 között, alapítója Bangha Béla. V.ö. Magyar Kultúra 2013. 
Egy másik előrebocsátandó szempont a történész és közönsége viszonya. A történetírás tárgyunkat érintő sajátosságaként el kell mondani, hogy a történetíróknak a történeti elbeszélés diszkutálásához nincs sajátos terminológiájuk. A történeti kutatáséhoz van, az előadáséhoz nincs (ami van, az az irodalomtudományé). A történetírás mint elbeszélés a retorikai teljesítmény egy sajátos formája. Ha a történészek egymás számára írnak, akkor inkább beszélnek a forrásaik nyelvén - ez a közönség számára érdektelen. Ha a közönséghez szólnak, akkor forrásaik nyelvi képződményeit át kell alakítani köznyelvi formára.

A történészek a közlési módok viszonylag széles választékával élhetnek. Amit hangsúlyozni kívánok, az a közönség múveltségének és a közlő nyelvi regiszterének a viszonya. Egy távolabbi példával élve: Gaál György (2011-2013) egy, a huszadik század elején (1907) történt rablógyilkosság kapcsán vizsgálta meg a magyar sajtó által a cigányokról közvetített képet. A vizsgálat során két hagyomány különült el. Az egyik a múvelt közönség sajtótermékeinek nyelvezete, a másik a szélesebb tömegekhez szóló sajtó cigányképe. Az elsőre a megértés és a nevelési optimizmus volt a jellemző, a másokra az antropológiailag pesszimista és etnicista szemlélet. A két hagyomány a rablógyilkosságig nem vett tudomást egymástól, onnan kezdve azonban a múvelt közönség sajtója áttért a tömegsajtó regiszterére. Az etnicizmust (egy esszenciális kulturális különbség tételezését) a részletes oksági magyarázat és az egyedi helyzet megértése pótlékának tekinthetjük. A Gaál György által leírt tünet hasonlít a morális pánik N. Smelser (1963) által leírt jelenségére. A bűneset után előállt a helyzet, amikor a művelt közönség egy részét már a morális pánik állapotában leledzőként kellett megszólítani.

Még egy megszorítást teszek. Nem foglalkozom a hatásukat tekintve csak szakmai berkeken belül maradt történészek antiszemitizmusával. Van példa, hogy valaki karrier okokból választotta a szélsőséges jobboldalt. ${ }^{8}$ Vannak, akiknél nem a karrier, hanem inkább a megélhetés a jobboldali radikalizálódás oka. ${ }^{9}$ Előbbi szerző a háború utáni emigrációban már szakmailag vitatott őstörténészként hatott szélesebb körben, utóbbi szerző múvei hatásukban nem jutottak a szakma körén túl - velük ezért nem foglalkozom. Szélsőjobboldaliakként bemutatta őket a Rubicon című történeti ismeretterjesztő folyóirat. ${ }^{10}$

A sok caveat után vissza a lényegre: a fölkérés úgy szólt, hogy beszéljek a két háború közötti történetírás antiszemitizmusáról. Az említett nehézségek miatt igyekszem elemzési irányokat kijelölni, és a történetírói teljesítményeket ezen irányok mentén besorolni. Mondanivalómat a hazai, nagyon tág értelemben vett történetírás néhány jellegzetes, bár nem egyformán ismert múve segítségével fogom, ha bizonyítani nem is, de legalább illusztrálni. Egyes esetekben kilépek az időbeni keretek közül is, de igyekszem mondanivalómat úgy felépíteni, hogy az ezek nélkül az excessusok nélkül is jótálljon magáért. A művek a következők: Szekfű Gyula (1920; 1922; 1934) Három nemzedékének különböző kiadásai; Farkas Gyulának (é.n.) Az asszimiláció kora címú irodalomtörténeti munkája; Mályusz Elemérnek (1928a; 1928b; 1931) néhány, a polgárság történetét érintő múve; Szabó István (é.n.) népiségtörténeti jellegű összefoglalója; Hajnal Istvánnak (é.n.) a korabeli reprezentatív magyar múvelődéstörténeti összefoglalóban megjelent, Az osztálytársadalom címet viselő fejezete; Erdei Ferenc (1980a) 1943. évi szárszói beszéde és egy ehhez kapcsolódó nagyobb lélegzetű, föltehetőleg egy tervezett könyvéhez készült kézirata (Erdei 1980b, 2010); Bibó Istvánnak (1986) a Zsidókérdés Magyarországon 1944 után címú ta8 Baráth Tibor. V.Ö. Borbándi 1992.

9 PI. Málnási Ödön. V.ö. Borbándi 1992; lásd még Paksa 2011.

10 Romsics 2004. 
nulmánya és - ehhez társulva - Ravasz Lászlónak (1988) egy 1960-ból származó kézirata a zsidókérdésről.

\section{BESZÉDMÓD}

A klasszikussá vált - tehát tartós és általános (de legalábbis a céhbelieken túl is) hatást gyakorló - történészek beszédmódját kétfelé választom. Az egyik fajtát nevezhetem pragmatikusnak vagy instrumentálisnak. A történészek egyik szerepelképzelése a korban a német historizmusból eredeztethető történészfejedelemé. A német történetírásban ilyen szerepet foglalt el magának Leopold von Ranke $(1885,2006)$ vagy Friedrich Meinecke. A történészfejedelem terepe a történetpolitika. E szerepfelfogás a következőképpen rekonstruálható: szemben a hagyományos elvárásokkal, a történelemnek nem feladata, hogy az élet tanítómestere legyen, hanem azt kell elmondania, amiként a dolgok tulajdonképpen voltak. A történész viszont a múlt megértésén keresztül képes felülemelkedni saját kora elfogultságain, s szellemi fölénye által részt venni a közéletben, sőt a nála nagyobb világi hatalmasságoknak méltó társa lenni. E szerepet hazánkban Szekfú Gyula kívánta és tudta betölteni. ${ }^{11}$ Szekfúnek azonban sajátos hazai okoknál fogva popularizálnia kellett szerepét. ${ }^{12} \mathrm{~A}$ korábban cinikus hangvételével (Szekfú 1913) világnézeti oldalakon túlnyúló sikert aratott Szekfű Gyula a történelmi Magyarország bukása után a személyes együttérzés és indulat regiszterében szólalt meg: a Három nemzedék múfajilag nem tanulmány, hanem egy nagyon terjedelmes röpirat. Tanulmányként közelítve hozzá joggal bírálható fogalomhasználata, következetlensége. Ez a közelítés azonban a mű célját - mely (történet)politikai - téveszti szem elől. Szekfú - mint meg is mondja - a háborús vereség utáni új rezsimnek kívánt tabula rasa-t teremteni. Ha e törekvés felől olvassuk a művét, és akként, hogy ezt a nézetét nem a szűk szakma, hanem a nagyközönség számára kívánta kifejteni, akkor mindaz, amit a másik, tárgyilagosságot számon kérő olvasat hibának minősített, a helyére kerül. A politikai (beszédaktus-jelleget föltételező) olvasatban Szekfú meg akarja szólítani közönségét, és ha erről a közönségről azt vélelmezi, hogy antiszemita érzületek rabja, akkor - belátható módon - a hatás érdekében ezen a nyelven kell szólnia, célját egyébként nem éri el. Ebben az olvasatban a Három nemzedék, ha filoszemitának vélt közönségnek íródott volna, akkor filoszemita szólamokat tartalmazna. A röpirat leglényegén sem ez, sem az nem változatna. Jellemző, hogy Bethlen István bukása és Gömbös Gyula kormányra kerülése után Szekfű Gyula egy - az eladdigitól nagyon eltérő „és ami utána következik”-et illesztett hozzá múvéhez.

Az iménti értelmezés szokás szerint fölveti a kérdést, vajon erkölcsileg elfogadható-e az értelmezés nyomán feltáruló történészi pozíció. Szekfű Gyulát általában is megalkuvónak, következetlennek szokták tartani. A történész, egész pályáját illetően, egy tekintetben életét és munkásságát illetően is következetes. A történészfejedelem történetpolitikai maximája, hogy az emigráns politikus (Kossuth Lajos vagy II. Rákóczi Ferenc) bukott, hogy ne mondjuk, halott politikus. Az instrumentális módon alkalmazott antiszemitizmus erkölcsi mérlegelését illetően az okoz zavart, hogy a szándéketika szokásos mércéi nem válnak be. A megítéléshez olyasfajta kérdéseket kellene, kellett volna már eddig is megvizsgálni, vajon az antiszemita közhelyek a korabeli közönség indulatainak felkorbácsolásához, vagy inkább azok csillapításához, esetleg szublimálásához, átcsatornázásához járultak-e hozzá.

11 Szekfű (1923) bevezetésében hangsúlyozottan Meinecke felfogását jelöli meg példaként.

12 Popularizálás alatt azt értem, hogy szerepében nem csak a szakmai, hanem szélesebb közönséghez szólt. Állításom nyilván hoszszabb bizonyítást igényelne. Jelen keretek között legyen elég utalni arra, hogy a magyarországi középosztály szűkebb, szegényebb és megosztottabb, mint német párja. Ezt fejezi ki Szekfú Gyula zsombék-hasonlata is. V.ö. Kövér 2006. 
Hosszabb távon a mú hatása recepciójával mérhető. Például Farkas Gyula (é.n.) irodalomtörténész $A z$ asszimiláció kora címú munkájának céljaként kifejezetten a Szekfű Gyula Három nemzedékében kifejtett nézetek továbbgondolását jelöli meg. Farkas - akinek fajvédő hajlamát nem kívánom kétségbe vonni - múvének célja az Arany János korát követő irodalmi élet elemzése. Tegyük hozzá, az anamnézis, miszerint az irodalmi élet jelentősen megváltozott, helyes, a diagnózis azonban, miszerint mindez a szemita szellem beszivárgásának volna köszönhető, nem meggyőző. ${ }^{13}$ Ami a téves diagnózisból ténylegesen a Három nemzedék hatásának tudható be, az ebben az olvasatban erkölcsileg felróható Szekfű Gyulának. ${ }^{14}$

Talán könnyebben megválaszolhatók az olyasfajta kérdések, mint például: nem lőtt-e túl Szekfü Gyula a javasolt olvasatban föltételezhető céljain, amikor félrevezette közönségét a kiegyezés utáni galíciai zsidó bevándorlás mértékét illetően. A nagymértékű bevándorlás tézisének megfogalmazásával egy tartós - a felülírási kísérleteknek ellenálló - téveszmét erősített meg. A galíciai bevándorlás mint történetszövési elem alkalmazása a politikai rezon felől nézve racionális: egyrészt a keresztény középosztállyal elfogadtatni a zsidó származású középosztály egyik részét, másrészt megosztani magát a zsidó közönséget. Mégis, ez az elbeszélési sarokpont jelzi is e szerepfelfogás határait (V.ö. Sándor 1984). A politikus hivatkozhat a pillanat szorító követelményeire, a történetpolitikus viszont nem számíthat arra, hogy publikációkban megnyilvánuló cselekedeteinek nem marad tartós nyoma.

A másik beszédmód a közvetlen névvel volna illethető - voltaképpen nem szerep, hanem azonosulás a vizsgálat tárgyával. Talán még az intencionális jelzőt akaszthatnók rá. A példa e beszédmódra Mályusz Elemér - a 20. századi történetírás szakmailag egyik legkiválóbb alakja - lehet. Mályusz több írásában is kifejtette meggyőződését, miszerint hazánkban a városi polgári középosztály (talán leginkább a német Mittelstandhoz hasonlítható eszmei képlet) mindig (tehát már a középkorban) is gyönge volt (értsd: tagjai nem töltötték be rendi szerepüket, például a kereskedést), és a zsidók - azáltal, hogy pótolták a polgárokat szerepükben - megakadályozták (szükségtelenné tették) azt is, hogy a városi polgárság felnőjön feladatához. Az újkorban Mályusz szerint a nemzeti hivatás az lett volna, hogy a városi polgárság összefogjon a nemességgel (erre történelmi példának Nyíregyháza megváltakozását - önkéntes örökváltságát - említi), de Mályusz nézete szerint e téren a zsidók által táplált internacionalizmus kerekedett felül. Mályusz kifejezetten úgy tartotta, hogy a hagyományos (és a nemzeti történetírás által rendszeresen idegen eredetúnek tekintett) hazai városi polgárság egyik jellegzetessége antiszemitizmusa volt. (Ez egyébként aligha túlzás, ha csak az 1848. évi forradalmi napok eseményeit tekintjük, akár a fő- és szék-, akár a vidéki városokban (Spira 1974).) Hangsúlyozni kell azonban, hogy az állítás nem a városi lakosságra, hanem az annak csak töredékét kitevő polgárjoggal rendelkező részre vonatkozik.) Az a tény, hogy Mályusz a városok polgárait antiszemitának tartja, természetesen még nem jelentene bizonyítékot a szerző antiszemitizmusára. Ez inkább ott mutatkozik meg, amikor „,kiszól” egyik vagy másik tanulmányából, ${ }^{15}$ hogy aztán kifejezetten is hangot adjon nézeteinek a kortárs történetírásról közölt cikksorozatában (Mályusz

13 Farkas kevéssé foglalkozott az olyan dologi tényezőkkel, mint az alfabetizáció vagy a nyomdatechnika változása.

14 Egy szándék-etika alapján lehetne úgy érvelni, hogy Szekfú nem tehet arról, mit kezdenek a szövegével. Abból kell azonban kiindulnunk, hogy történetpolitikusként nyilatkozik. Egy politikus cselekedetét úgy kell értelmeznem, mintha megbízás alapján történnék. Ebben az esetben nem a szándék, hanem az eredmény számít (Max Webernél: felelősség etika).

15 Pl.: Mályusz 1928b, ahol Mályusz az amúgy a középkorról szóló szövege végén hirtelen évszázadokat ugorva tesz a zsidók szerepét kárhoztató megjegyzést. 
é.n.). Mályusz ez utóbbi írásai alapján akár zsidóellenesként is besorolható.

\section{SZÓTÁR}

Nem beszédmód, inkább szótár kérdése fajiság és antiszemitizmus kapcsolata, amely például a Mályusz Elemér által kezdeményezett népiségtörténet kapcsán merül föl kérdésként. A népiségtörténetet a nemzetiszocialista Németország által támogatott irányzatként tartják számon. Megítélését nehezíti, hogy az irányzat szakmailag újat hozott a történetírásban, miközben politikailag a német terjeszkedés eszköze volt. Mályusz Elemér az irányzat meghonosítását két okból javasolta. Ellensúlyozni kívánta egyrészt a német terjeszkedési törekvéseket. A másik ok a félelem volt, a félelem attól, hogy a történeti Magyarország területén létrejött új államoknak a volt országból rájuk maradt kulturális emlékekkel szemben táplált indulatai pusztítóvá fokozódnak.

A két ok összefügg. Fölvetődhetik, vajon miért támogatta a német törekvéseket ellensúlyozni kívánó Mályusz a nemzetiszocialista Német Birodalom által támogatott irányzatot. A válasz legegyszerúbben a „kutyaharapást szőrivel” mondással summázható. Az magától értetődő, hogy a német támogatás ösztöndíjakat jelentett német kutatóknak. Az már kevésbé, mégis így volt, hogy német kutatókat a magyar kultuszkormányzat is támogatott. Mályusz a hazai szakmai utánpótlás támogatását szerette volna elérni, és azt is, hogy a hazai utánpótlás a civilizációs és kulturális emlékek megmentésében vegyen részt. Ehhez a német irányzat módszerei - amelyek a hajdani falukutatási és szociográfiai módszerek kiterjesztései voltak - tökéletesen megfeleltek.

A Mályusz-féle népiségtörténet inkább módszer és - a helytörténet-írás fejlesztésén alapuló - kutatási program, mint ideológia, melyhez azonban a faj fogalmának kulturális alapú értelmezése társult. Az irányzat eredményei is inkább fiatal történészek által készített szakmunkák voltak. ${ }^{16}$

Szakszerű, de a szélesebb közönséghez is szólni kívánó művet Szabó István írt. Ő eredendően településés agrár- (vagy ha tetszik: parasztság-)történész volt, bár a Magyarság életrajza címú múben szóba kerülnek a zsidók és említtetik a zsidóság. Könyvében fontos szerepet kap az asszimiláció kérdése, és szigorú elemzésben Szabó István e kérdésben kifejtett gondolatai ellentétesek volnának az asszimiláció liberális elgondolásával. Szabó ugyanis a nemzeti asszimilációt nem az egyének tudatosan választott külsődleges (beszéd, viselet s.í.t.), hanem azok tudattalan kulturális megnyilvánulásaihoz, hogy ne mondjuk szellemiségéhez, (korabeli szóhasználattal) fajiságához kötötte. ${ }^{17}$ Szabó kritériumait alkalmazva mérceként, a zsidók 19-20. századi asszimilációja a közvélekedéshez képest föltehetőleg csak sokkal kisebb mértékben valósult meg. ${ }^{18}$ Ennek ellenére a szerzőt nehéz volna antiszemita érzülettel vádolni. Személyes vélekedésem, hogy a tények értelmezésében követett szigorúság hozzájárulhatott ahhoz, hogy nézetei következményeit illetően Szabó István nem kényszerült paradigmamentő bukfencekre (haszonelvűség, hálátlanság), és így mentes maradhatott az antiszemitizmustól is.

Talán ebben az alfejezetben említhetem meg különös esetként Ungár László példáját. ${ }^{19} \mathrm{~A}$ tragikus sor-

16 Rövid összefoglalását I.: Szőts 2014.

17 Ezt ma talán a kulturális emlékezetbe való beilleszkedéssel fejeznők ki.

18 A kérdés irodalma lassan terebélyesedik: Gyáni 1993, Erős 2005, Bolgár 2006.

19 A „talán” arra vonatkozik, hogy Ungár - bár jelent meg tanulmánya a múvelt középosztálynak szánt Domanovszky-féle Magyar múvelődéstörténet záró kötetében is (Ungár, é.n.) - nem sorolható a közvéleményt komolyabban befolyásoló történészek közé. 
sú történész származása szerint zsidó volt. ${ }^{20}$ Ungár legfontosabb múve tanulmány-trilógiája. ${ }^{21} \mathrm{~A}$ Századok c. folyóiratban megjelent három cikkében a hazai polgári átalakulás egy-egy kulcsmozzanatát ragadta meg. Az egyikben az új rétegek létrejöttét vázolta, a másikban a régiek hanyatlását, a harmadikban a régi és feltörekvő csoportok viszonyát - a nemesi birtokok eladósodása kapcsán. Utóbbi történet szereplői részben zsidó hitelezők, akik a szövegben előnytelen beállításban is szerepelnek (Ungár 1935:46-47). A szokásos megoldás-feloldás a zsidó öngyúlöletre való utalás volna. Nézetem szerint sokkal inkább a szótár hatalmáról, a nemesi történeti elbeszélésmód, narratíva szándékolatlan átvételéről van szó. A tanulmány az eladósodás jelenségéről nem csak adatok alapján szól - ezekből a kérdés taglalásához nem is volt elegendő. A történésznek föl kellett használnia a forrásként rendelkezésre álló elbeszéléseket is. Ezeket azonban csak megfelelő előzetes értelmezési keret mellett lehet tényekké alakítani - a történész ki van szolgáltatva „segédtudományainak”. Ungár esetében a kutatások még messze nem tartottak ott, hogy a kérdést közgazdaságtani módszerekkel lehetett volna vizsgálni. A szerzőnek nem sikerült a kellő távolságot megteremtenie, de más lehetősége nem lett volna, hacsak a kérdéssel egyáltalán nem foglalkozik.

\section{BESZÉDMÓD ÉS SZÓTÁR}

Erdei Ferenc talán legjellemzőbb vonása besorolhatatlansága. Szociális helyzetét tekintve kilépett családja földmúves világából, de nem törleszkedett ahhoz az értelmiségi közeghez, amelyik akár be is fogadta volna. Jó kapcsolatai voltak úgy a református, mint a kommunista miliőhöz. Fiatalkori messianizmusa érettebb korára politikai radikalizmussá alakult át, lett légyen az szabó dezsői fajvédelem, vagy nemzeti kommunizmus. Nem volt hivatásos történész, mégis nagyobb hatást gyakorolt a történetírásra, mint megannyi céhes mester. Témánk szempontjából legfontosabb hagyatéka a nevéhez kötött kettős társadalom címkéjū szellemi építmény. Mivel tapasztalatom szerint nem közismert, röviden összefoglalom a társadalomtudományi elméletként is szolgáló történeti elbeszéléssel kapcsolatos újabb historiográfiai kutatási eredményeket. Amit korábban is tudtunk (más kérdés, jól-e), az részben Erdei Ferencnek a marxizmushoz való viszonya (Huszár 1979), másrészt a szövegében felbukkanó antiszemita klisék elemzése volt (Kovács-Melegh 1997). Ehhez képest a szerző születésének centenáriuma körül készült publikációk (Szociológiai Szemle 2010, Bognár 2010) rámutattak Szabó Dezső hatására és tisztázni igyekeztek a vonatkozó Erdei-szövegek egymáshoz való viszonyát. Ez utóbbi téren a következők derültek ki. Erdei Ferenc 1943. augusztusában elmondta a szárszói beszédnek nevezett politikai programszövegét. A beszédet a konferencia után közzétették - ma már tudható, hogy az írásban megjelent szöveg nem volt azonos a szóban elhangzott változattal. ${ }^{22} \mathrm{Az}$ írásos változat harmadik, legrövidebb része a magyar társadalom szerkezetével foglalkozott. A konferenciakötetbeli hirdetés alapján tudható, hogy erről a témáról Erdei Ferenc nagyobb lélegzetű múvet kívánt írni, amely azonban nem jelent meg. Föltehető, hogy ennek a készülő könyvnek a kézirata volt az, amelyiket a Valóság című folyóiratban 1976-ban Huszár Tibor közzétette (Erdei 1980b). A kézirat fénymásolata még megvan, de az eredeti a szerző hagyatékának kézirattárba szállításakor már nem volt fellelhető. A kézirattári anyag átvizsgálásakor viszont kiderült, hogy eladdig lappangott a kéziratnak a harmadik, „történelmi népi” társadalommal, tartalmilag a parasztsággal foglalkozó része (Erdei 2010).

20 Élettörténetére: Gajáry 2004.

21 Ungár 1935, Ungár 1938, Ungár 1942.

22 Egy ránk maradt kézirat (Halmos 1943) alapján. 
A szárszói beszéd lényege, hogy történelmi távlatból nézve a magyar társadalom fejlődésében fordulat csak külső, idegen hatásra szokott bekövetkezni. A különböző társadalmi csoportok vezető rétegei hitelüket veszítették, változás a középosztály reformot óhajtó fiatal nemzedékétől, a munkásság népi és a parasztság kitörni vágyó elemeitől várható. Témánk szempontjából érdemes kiemelni az idegen erőkbe vetett hitet és azt, hogy a munkásosztály vezetésében úgy a zsidó származású baloldali, mint a nyilas vezető réteg csődöt mondott. A népi elem elitjének feladata az írásos szöveg szerint az, hogy a politika támogatásával tartóssá tegye a potens elemek (adott esetben a munkásosztály) által kezdeményezett változtatásokat.

A program háttereként szolgáló leírás dokumentálatlan, szigorúan véve nem tudományos. A szöveg antiszemita megfogalmazásait már korábban észlelték (Kovács-Melegh 1997), magam ehhez csak annyit teszek hozzá, hogy ezeket a megfogalmazásokat egy fajvédő program megnyilvánulásainak tudom be.

Az 1976. évi publikációkban részletezett társadalomszerkezeti képlet érintőlegesen már a beszédben is megjelenik.

„E polgárság legnagyobbrészt idegenekből toborzódott, azonban asszimilálódott is a magyar vezető rétegekhez. Ezenkivül lojális is volt e vezetéshez az egész [18]67-es korszakon keresztül. A 90-es évekre azonban ez a polgári társadalom már olyan arányokban kiépült, hogy önálló eröket és törekvéseket tudott képviselni a konzervativ nemesi-nemzeti társadalommal szemben. Önállóságának jeleként az egész társadalmi életben új elemek jelentkeztek, és új ellentétek ütköztek ki. Az irodalmi életünkben jelentkező sajátságos kettészakadás ennek a társadalmi helyzetnek a következménye. A konzervativ nemzeti társadalom klasszikus irodalma helyett egy nyugtalan, új törekvéseket és új hangot képviselö irodalom lépett fel, amelyben ez a friss, polgári társadalom és benne elsősorban a zsidóság jelentkezett." (Erdei 1980a)23

A leírás előképe már Szekfű Gyulának az első világháború alatt írt, A magyar állam életrajza című múvében megjelent: „Az új erők új képződményeket hoztak létre, melyek a lassú történeti fejlődésben létrejöttel még nincsenek szerves kapcsolatban" (Szekfü 1923:199). Szekfü a szervetlenségre helyezi a hangsúlyt, de azt nem társítja valamiféle zsidó faji jelleggel. Erdei szerint a zsidótörvények hatálya alatt a történelmi nemzeti társadalom részben zsidó mintákat kezdett követni: „az úri középosztály és a keresztény nemzeti kispolgárság elemei belekerültek a polgári pozíciókba, és ott a régebbi polgárság, tehát jelentékeny részben zsidóság által kialakitott formákban folytatták a gazdasági tevékenységet" (Erdei 1980a: 363). A történelmi helyzet értékelése szokatlan. Állításomat, miszerint Erdei nem antiszemita, hanem fajvédő, lényegében erre a beállításra alapozom, de más érvet is hozok. A szárszói beszéd összesen háromszor említ „zsidóságot”. Az egyik a már említett eset. A másik az irodalmi élet személyi állományát minősíti - az irodalom kérdésére a következő bekezdésben visszatérek. A harmadik alkalom pedig egy olyan szöveghely, ahol Erdei a faji szemléletet az ő szemszögéből - de nem az ő kifejezésével - „elfajzott” középosztálynak tulajdonítja:

„A történelmi alakulás során számos nemzetiségi elemet szivott fel magába, és a beömlések azt a magyar népiséget, amely még sajátja volt a reformkor nemességének, egy század alatt nagymértékben felhígították

23 A „történelmi népi” kifejezésként a beszéd szövegében még nem jelenik meg, az 1976-ban közölt kéziratokban utalásként már igen. A 2010. évi szövegkiadásból kiderül: Erdei Ferenc egy korábbi írása alapján, kevésbé tollal és irónnal, mint inkább másolással és kihúzással elkészítette, bár nem fejezte be a harmadik társadalomfél leírását is. V.ö. Halmos 2010. 
német és szláv elemekkel. Ezért van az, hogy a parasztságot magával szemben idegennek, a maga számára már nehezen érthetően tartja magyarnak, viszont a polgárságot szinte egészében zsidóságnak érzi." (Erdei 1980a: 366)

Minthogy Erdei a zsidóságot az irodalom kapcsán is megemlíti, erre a kérdésre külön is kitérek. A szárszói beszéd szövegét szigorúan olvasva, Erdei egy irodalmi életet, de több irodalmat megemlít. Szerinte hazánkban két irodalmi tradíció él egymás mellett, és a különböző tradíciók mögött különböző társadalmak húzódnak meg. A hangsúly a társadalmi képletek és az irodalmak viszonyán van - Erdei úgy tartja, hogy az irodalmi ellentétek társadalmiak következményei. Ez lehet marxista behatás, de nem ez a lényeg. Még ha az is, az alap-felépítmény aszimmetriát Erdei saját érdekében használta ki, hiszen evvel azt tudta állítani, hogy a jelentős népi irodalom mögött jelentős népi erőnek kell állnia. ${ }^{24}$

\section{IDEGENKEDÉS ÉS ANTISZEMITIZMUS}

A szorosan vett témát lezárandó hozom szóba a kérdést, mi a viszonya idegenkedésnek és antiszemitizmusnak. Miskolczy Ambrus már korábban említett kétrészes cikkében (Miskolczy 2012) sorra vette és kipellengérezte történészeink antiszemita megnyilvánulásait. Az egyik tárgyalt személyiség Hajnal István volt.

A két háború közötti reprezentatív történelmi múvek szerzőihez (Hóman Bálint, Szekfü Gyula) és szerkesztőihez (az eddigiek mellett: Kerényi Károly, Domanovszky Sándor) képest Hajnal István neve kevésbé ismert a szélesebb közönség előtt. Jóval kevésbé volt (történet-)politikus, mint az imént említettek közül hárman is (Hóman, Szekfú, Domanovszky). Felületesen tekintve teljesen hagyományos történészi téma, a középkori kancelláriák írásbelisége vizsgálatával kezdte pályáját, amelyet később általános írástörténeti vizsgálódássá szélesbített ki. Az írást nem szimbólumképző cselekvésként, hanem kalligrafáló ténykedésként szemlélte. Mivel nemcsak az ismereteket, hanem a készségeket is tudásnak tekintette, nem meglepő, hogy a formaképzés iránti érdeklődése a technikatörténet áttekintése felé vezette. A formaképzés és-képződés kutatása elengedhetetlenné tette a formaképzők, azaz írásokat és gépeket létrehozó és múködtető emberi együtt élő közösségek vizsgálatát. Meglátása szerint az új tudás megszerzésének alapját a szilárd szokások képezték, és az észelvű okoskodás önmagában nemhogy integrálta, de inkább szétfeszítette az emberi társadalmakat.

Történészi gondolkodásának eredményei az európai középkor újraértékelésére késztették. Úgy vélte, az ipari forradalom és a modern kapitalizmus nem a középkor ellenében, hanem annak évszázados ismeretfölhalmozását jó esetben föl-, rossz esetben kihasználva jött létre. A magánéletét tekintve a keresztény középosztály normáinak megfelelően élt egyetemi tanár, gondolatilag az egyik legeredetibb magyar történész volt, aki azonban nehézkes, szinte titokzatos nyelvezettel fejtette ki gondolatait. Saját korában (akadémiai székfoglalója után) úgy érzékelte, hogy közönsége marxistának tartotta. Múvének utóélete hosszabb, már életében megkezdődött felejtéssel indult. Ebben az időben Hajnal István nevét az angolszász kommunikációelmélet inkább tartotta nyilván, mint a hazai historiográfia. Később Erdei Ferenc és Bibó István életművének vizsgálata irányította Hajnal

24 A magyar irodalomban felbukkanó társadalomképek értelmezését az irodalom egy hajdani szegedi professzora, Sándor István végezte el. Azt még nem tudjuk, vajon múve vagy annak előkészületei hathattak-e Erdeire, de a hasonlóság feltűnő. Természetesen a különbség figyelembe vétele után: Sándor István az írásmúvek tartalmából azok szerzőire, míg Erdei a múvek megfogalmazásaiból azok valóságosságára következtetett vissza. V.ö. Sándor 2012. 
István felé is a kutatók figyelmét, s a vizsgálódók rámutattak Oswald Sprenglerhez, Max Weberhez, illetve Émile Durkheimhez fúződő szellemi viszonyára.

A rokonszenvező befogadási szakasz után manapság megjelent a szerzővel bár nem ellenszenvező hangú, de esetét a "legtragikusabb és a legfájdalmasabb"-nak (Miskolczy 2012:20-26) minősítő értékelése is. Miskolczy Ambrus azt állítja, hogy a zsidóellenes közhangulatnak engedő Hajnal Istvánnak voltak antiszemita megnyilvánulásai. Mivel ez az értékelés még meglehetősen friss, pár mondatban kitérek rá, illetve a szembeszegezhető ellenérvekre. Tény és való, Hajnal múveiben is találhatók néhol a zsidó szellemtôl való idegenkedésről árulkodó megjegyzések, de ezek - a korszellemet is figyelembe véve - enyhék és ritkák. Miskolczy Ambrus két tényt említ. Az egyik egy kéziratban maradt szöveghely. Kérdés, érdemes-e antiszemita megnyilvánulásnak tekinteni valamit, amit nem adtak közre. A két háború közötti keresztény középosztály (ahová a történetírók jó része tartozott) megítélése tekintetében ez nem közömbös kérdés. Hajnal bár papírra vetette meglátásait, de nem adta közre, és föltehetőleg nem is terjesztette őket - filozofikusan fogalmazva: gondolata tárgyiasult, de nem dologiasodott. Meddig tart az antiszemitizmus, van-e helye a magánszférabeli idegenkedésnek, vagy mindent egyöntetűen az antiszemitizmus kategóriája alá kell vonni? Ha megtesszük, nem jutunk-e túl gyorsan a gondolatbűnök lehetőségének elfogadásához? Nézetem szerint ebben az esetben morálisan, és az adott közegben inkább a visszatartás aktusát, mint a gondolat papírra vetésének vétkét kellene többre értékelni. A másik egy olyan szöveghely, ${ }^{25}$ amelyet Miskolczy kódolt beszédnek ${ }^{26}$ minősít. Evvel kapcsolatban nem magától értetődő és további magyarázatot igényelne, hogy valaki, aki a közönsége körében - Miskolczy szerint is - eluralkodott antiszemitizmusra kívánna rájátszani, kódolva fogalmazza meg mondandóját. Egyetértve Miskolczy Ambrusnak a zsidóellenes korhangulatra vonatkozó vélelmével, akár - mint Szekfú esetében - elemezhető föltevés lehet, hogy Hajnal éppenséggel formálni, értelmezés által kézben tarthatóvá szerette volna tenni olvasói ösztönös indulatait. $^{27}$

\section{ZSIDÓKÉRDÉS ÉS ANTISZEMITIZMUS}

Mintegy függelékként, hiszen nem illeszkedik a kitűzött korszakhatárok közé, még két, egymáshoz intellektuálisan erősen kapcsolódó szerzőre térek ki. Bibó Istvánról és Ravasz Lászlóról van szó. Szerepeltetésüket az indokolja, hogy Bibó István a háború után, a következmények feldolgozását megkönnyítendő, megkísérelte végiggondolni az ország újkori történelmét. Ilyen jellegű tanulmányainak csúcspontja a „zsidókérdést” tematizáló múve (Bibó 1986). Ebben az írásában Bibó István megkísérelte zsidók és nem zsidók viszonyát megértő, terapeutikus módon tárgyalni és ezáltal közönsége szemében a zsidókérdést érvényteleníteni. ${ }^{28}$ Bibót familiáris kapcsolat fúzte Ravasz Lászlóhoz, a magyarországi református egyház egyik nagy hatású püspökéhez. ${ }^{29}$

25 „A csupán kalkulációval dolgozó szakszerüség szinte vonzza a vezetésre a társadalomban addig idegen elemeket, a zsidóságot. S amikor a magyar intelligencia sürgeti a gyakorlati gazdasági pályákon való elhelyezkedést, szintén kevésbé a hivatástudat s a szakszerü feladat, hanem inkább a szerzéslehetőségek ösztönzik” (Hajnal é.n.:195-196). Miskolczynál „szerzéslehetőségek” helyett „szerzés lehetősége” (Miskolczy 2012:24) áll - a különbség ebben az esetben lényeges.

26 „Durva prózában: a zsidók és az elzsidósodottak az emberi spontaneitást és a szerves társadalomalakulást maga alá gyürő racionalitás és racionális mechanika hordozói. Jellegzetes, ám máig is jól kódolt formákban felbukkanó közhely" (Miskolczy 2012:24).

27 Az előző bekezdések némi különbséggel megjelentek: Halmos 2014.

28 Más véleményen van erről Gyáni 2011.

29 A református egyház belső törésvonalairól szól Szász 2014. 
Míg az köztudott, hogy Bibó vonatkozó tanulmányának címe Zsidókérdés Magyarországon 1944 után, az már kevésbé, hogy apósa A zsidókérdés Magyarországon címmel tett közzé írást 1938-ban (Ravasz 1938) - mely írás egyébként az első zsidótörvény kapcsán elmondott felsőházi beszédét tartalmazta. ${ }^{30}$ Ravasz László ehelyütt és másutt is hangsúlyozta, hogy a zsidókhoz való viszonyát illetően álláspontját már 1917-ben kifejtette, és az az idők során nem változott. Akkoron még a Huszadik Század körkérdése számára fejtette ki nézetét (Ravasz 1917), miszerint a zsidók iránti felebaráti szeretete miatt ellene van a zsidóságnak (ez tulajdonképpen a hittérítés logikája). Ehhez az álláspontjához következetesen ragaszkodott, nem csak politikai beszédeiben, hanem például a Soli Deo Gloria diákjainak körkérdésére válaszolva (Ravasz é.n.), vagy akár a háború után is (Ravasz 1988). A teológiai álláspontnak súlyos politikai következményei voltak.

Evvel együtt is, annak, hogy Ravasz László a felsőházban az első két zsidótörvény mellett szavazott, nézetem szerint egy egyházpolitikai csapda volt az oka (Halmos 2011). Nevezetesen a felsőházi tagként egyháza politikai képviseletét magára vállaló püspökként, tehát választott vezetőként kellett szavazatát mérlegelnie. Ismét csak az instrumentális vagy pragmatikus beszédmód egyik példányáról van. ${ }^{31}$ Nyilván volt tudomása arról, mekkora a zsidóellenesség az egyházában, illetve lehettek elképzelései, mi szükséges nyája egyben tartása érdekében. A döntését igazoló vagy cáfoló helyzet az 1944. év, a soá lett, amikor az egyházaknak a széthullott és abuzált állam helyett és ellenére kellett tevékenykedniük. ${ }^{32}$

Bibó István háború előtti álláspontja fajvédőnek nevezhető. Az első zsidótörvény után azonban a korábban minden bizonnyal meggyőződéssel képviselt álláspont puszta nyelvi eszközzé változott. A Márciusi Front 1938-as programjának készítésekor az antiszemitizmus nyelvét használja, de nem szelleme szól általa, nem a zsidókat, hanem a helyükbe lépetteket jelölvén meg ellenfélnek, akik a zsidókra mutogatással saját üzelmeikről terelnék el a gyanút (Bognár 2011; Huszár 1991).

Az előadás eredeti célja a két háború közötti történészi antiszemitizmus bemutatása volt. Igyekeztem a kérdést szétbontani. Rámutattam arra, hogy csak viszonylag kevés történésznek adatott meg, hogy tudományos vagy világnézeti álláspontját szélesebb közönséghez juttassa el. A történészeken kívül szó esett olyanokról is, akik bár nem voltak történészek, de a történelmi kifejtés közlési módjuk jelentős eszköze volt. A nagy hatású történészek között alig voltak, akik nyers zsidóellenességgel lettek volna vádolhatók. Az antiszemitizmust pragmatikus szemlélete kimozdítja ugyan a morális térből, de nem menti, csak megítélésének kritériumait módosítja.

Végszóként érdemes utalni arra, hogy az említett szerzők pályája így vagy úgy a háború után is folytatódott - igen eltérő módokon azonban: az egzisztenciálisan ellehetetlenített Hajnal Istvántól a fontos állami tisztségeket betöltő Szekfű Gyuláig. A Kádár-kornak is szürke eminenciása volt Erdei Ferenc, megbecsült akadémiai kutató maradt Mályusz Elemér. Egy szóval összegezhetetlen Bibó István pályafutása a közvélekedés előtt rejtve 30 Érdemes megfigyelni a határozott névelő hiányát, illetve használatát az egyik, illetve a másik esetben.

31 Erre vonatkozóan említésszerűen I.: Halmos 2010:1057-1058.

32 Úgy tudom, a zsidónak minősítettek mentésében az egyházak tudták a legtöbbet tenni. Ha ez igaz, akkor innen visszatekintve - és utalva az felelősség-etikáról mondottakra - kell mérlegelni, vajon a nyáj egybentartása, vagy egy esetleges szakítás lett volna-e jobb döntés. 
maradt fajvédelemtől az 1956. évi forradalmi szerepvállalásig. Fontosnak tartom leszögezni azonban, hogy nehéz volna bármiféle kapcsolatot találni az antiszemitizmus mértéke és a későbbi pálya iránya között.

\section{HIVATKOZÁSOK}

Acsády I. (1944) A magyar jobbágyság története (1906). Faust, Budapest. Elérhető: http://mek.oszk.hu/13500/13545/\# (Letöltve: 2015-05-17)

Bibó I. (1986) [1948] Zsidókérdés Magyarországon 1944 után. In Bibó I. Válogatott tanulmányok 2.: 1945-1949. Vida István (szerk). Magvető, Budapest. 621-797. Elérhető: http://mek.oszk.hu/02000/02043/html/362.html (Letöltve: 2015-05-17)

Bognár B. (2010) Erdei Ferenc szociológiája. Loisir, Budapest.

Bognár B. (2011) Szabó Dezső harmadik utassága és a Márciusi Front politikai programja. Valóság 4, 11-24.

Bolgár D. (2006) Asszimiláció a térben. Kísérlet Szabó István asszimiláció koncepciójának kibontására. Sic Itur ad Astra 1-2, 43-72.

Borbándi Gy. (1992) Nyugati magyar irodalmi lexikon és bibliográfia. Hitel, Budapest. Elérhető: http://mek.oszk.hu/04000/04038/ html/b.htm (Letöltve: 2015-05-17)

Censor [Beksics Gusztáv] (2005) [1884] Társadalmunk és nemzeti hivatásunk. In Müller R. Beksics Gusztáv. Új Mandátum, Budapest.

Erdei F. (1980a) [1943] A magyar társadalom. Előadás. In Erdei F. A magyar társadalomról. Akadémiai, Budapest. (347)-(372). Elérhető: http://mek.oszk.hu/05900/05942/html/gmerdei0002.html (Letöltve: 2015-05-17)

Erdei F. (1980b) [1943-44, 1976] A magyar társadalom a két háború között. In Erdei F. A magyar társadalomról. Akadémiai, Budapest. (293)-(346) URL: http://hu.scribd.com/doc/103982265/Erdei-Ferenc-A-magyar-tarsadalom-a-ket-haboru-kozott-in-u\%C5\%91-A-magyar-tarsadalomrol-Budapest-Akademiai-1980-291-346

Erdei F. (2010) Történelmi népi társadalom (IV. A paraszttársadalom). Szociológiai Szemle 3, 12-42. Elérhető: http://www.szociologia. hu/dynamic/sz_sz_2010_4_web.pdf (Letöltve: 2015-05-17)

Erős V. (2005) Asszimiláció és retorika. In Erős V. Asszimiláció és retorika. Szabó István: A magyar asszimiláció címü müvének rekonstrukciója. Disputa, Debrecen. 75-118.

Farkas Gy. (é.n.) [1938] Az asszimiláció kora a magyar irodalomban 1867-1914. Magyar Történelmi Társulat, Budapest.

Gaál Gy. (2011-2013) A cigánykép változása a sajtóban egy mikrotörténeti vizsgálat tükrében. Kút, 91-101.

Gajáry I. (2004) Egy kettétört tudóspálya. Ungár László vázlatos életrajza. In Sipos András (szerk.) Magyar levéltáros életpályák a XIXXX. században. Budapest Főváros Levéltára, Budapest. 109-119.

Gyáni G. (1993) Az asszimiláció fogalma a magyar társadalomtörténetben. Valóság 4, 18-27.

Gyáni G. (2011) Az asszimilációkritika Bibó István gondolkodásában. Holmi 8, 1022-1035. Elérhető: http://epa.oszk. hu/01000/01050/00092/pdf/holmi_2011_08_1022-1035.pdf

Hajnal I. (é.n.) Az osztálytársadalom [1943]. In Miskolczy Gy. (szerk.) Az új Magyarország. Domanovszky S. (szerk.) Magyar Müvelödéstörténet 5. Magyar Történelmi Társulat, h.n. 163-200. Elérhető: http://mek.oszk.hu/09100/09175/html/78.html (Letöltve: 2015-05-17)

Halmos B. (1943) Szárszói konferencia. Halmos Béla épitészmérnök. 1943. Kézirat. [id. Halmos Béla építészmérnök följegyzései Kósa László őrizetében].

Halmos K. (2010) A történelmi népi társadalom. A magyar társadalom a két háború között címú tanulmány negyedik része. Szociológiai Szemle 4, 2010, 4-11. Elérhető: http://www.szociologia.hu/dynamic/sz_sz_2010_4_web.pdf (Letöltve: 2015-05-17)

Halmos K. (2011) Teológiai politika. [...] Holmi 8, 1052-1060. Elérhető: http://www.holmi.org/2011/08/9179 (Letöltve: 2015-05-17)

Halmos K. (2014) Társadalomtörténet a segítők képzésében. Függelék. Beszélő Online 2014.03.25. Elérhető: http://beszelo.c3.hu/ keretes/fuggelek (Letöltve: 2015-05-17)

Huszár T. (1979) Történelem és szociológia. Magvető, Budapest.

Huszár T. (1991) Párhuzamok és kereszteződések. Erdei Ferenc, Bibó István és a Márciusi Front. ELTE Szociológiai Intézet - Makói József Attila Múzeum, Budapest-Makó.

Kovács É. - Melegh A. (1997) Tükör által homályosan. Kísérlet Erdei Ferenc „A magyar társadalom a két világháború között” című tanulmányának rekonstrukciójára. In Szabó M. (szerk). Szövegvalóság. Írások a szimbolikus és diszkurzív politikáról. Scientia Humana, Budapest. 133-158. 
Kövér Gy. (2006) Előszó. In Kövér Gy. (szerk.) Zsombékok: Középosztályok és iskoláztatás Magyarországon a 19. század elejétól a 20. század közepéig. Budapest: Századvég Kiadó, 9-12.

Lengyel András (1991) Németh László Shylock-metaforája. Egy metafora értelme és eszmetörténeti szerepe. Valóság 8, 56-74.

Magyar Kultúra (2013) Magyar Kultúra (1913-1944). Arcanum Adatbázis, Budapest. Elérhető: http://www.arcanum.hu/kiadvanyaink/ folyoirat/?id=MKLT (Letöltve: 2015-05-17)

Mályusz E. (é.n.) [1942] A magyar történettudomány. Bolyai Akadémia - Turul Szövetség Könyv- és Lapterjesztő, Budapest.

Mályusz E. (1928a) Kossuth múködésének társadalomtörténeti háttere. Napkelet 3, 166-183.

Mályusz, E. (1928b) Geschichte des Bürgertums in Ungarn. Vierteljahrschrift für Sozial- und Wirtschaftsgeschichte. 356-407.

Mályusz E. (1931) A magyarországi polgárság a francia forradalom korában. A Bécsi Magyar Történeti Intézet Évkönyve I. $225-282$.

Marx, K. (1957) [1844] A zsidókérdéshez. Karl Marx és Friedrich Engels Múvei 1. Kossuth, Budapest. 349-377. Elérhető: http://www. freepress-freespeech.com/holhome/konyvek/marxm.htm (Letöltve: 2015-05-17)

Miskolczy A. (2012) „....igen, de...”. Antiszemitizmus és történetírás Hunniában I., II. 2000 9. 11-26.; 2000 10. 15-23. Elérhető: http:// ketezer.hu/2012/09/miskolczy-ambrus-igen-de-i-resz/; http://ketezer.hu/2012/10/igen-de-ii-resz/ (Letöltve: 2015-05-17)

Paksa R. (2011) Pártbomlás vagy bomlott elme? Málnási Ödön Szálasi-jellemzésének forrásértékéhez. In „... nem leleplezni, hanem megismerni és megérteni" (Romsics Ignác). Tanulmányok a 60 éves Romsics Ignác tiszteletére. Gebei S. - ifj. Bertényi I. Rainer M. J. (szerk) Líceum, Eger. 402-410.

Ranke, L. von (1885) [1824] Geschichten romanischer u. germanischer Völker von 1494 bis 1514. Duncker und Humblot, Berlin. Elérhető: https://archive.org/details/geschichtenderro00rankuoft (Letöltve: 2015-05-17).

Ranke, L. von (2006) [1854] Az újabbkori történelem szakaszairól. In Gyurgyák J. - Kisantal T. (szerk.) Történetelmélet 2. Osiris, Budapest, 1043-1049.

Ravasz L. (1917) Dr. Ravasz László teológiai tanár, a „Protestáns Szemle” szerkesztője (Kolozsvár). In Alexander B. et al. A zsidókérdés Magyarországon. A Huszadik Század körkérdése. A Huszadik Század Könyvtára 64. Társadalomtudományi Társaság, Budapest, 126-129. Elérhető: http://www.fszek.hu/mtda/_Zsidokerdes.pdf (Letöltve: 2015-05-17)

Ravasz L. (é.n.) A zsidókérdés megoldása [1933]. In Kiss A. et al. A nagy per. Soli Deo Gloria, Budapest. 105-110.

Ravasz L. (1938) A zsidókérdés Magyarországon. Hitel 2, 97-106.

Ravasz L. (1988) A zsidókérdésről [1960]. In Ravasz L. Válogatott írások 1945-1968. Európai Protestáns Magyar Szabadegyetem, Bern. 353-370.

Rigó, M. (2012) A Hungarian version of the Historikerstreit? A summary of the Romsics-Gerő debate among Hungarian historians. Imre Kertész Kolleg, Jena. Version: 1.0, 25.06.2013, Elérhető: http://www.imre-kertesz-kolleg.uni-jena.de/index.php?id=415\&l=0 (Letöltve: 2015-05-17)

Romsics G. (2004) A magyar történelem völkisch ábrázolásai. Hogyan alakult a hazai szélsőjobboldal történeti diskurzusa a Horthykorszak végén? Rubicon 11,69-75. Elérhető: http://www.rubicon.hu/megrendelheto/termek_cikkek/romsics_gergely_a_magyar_tortenelem_volkisch_abrazolasai_hogyan_alakult_a_hazai_szelsojobboldal_tort/51/11/0 (Letöltve: 2015-05-17)

Sándor A. (1984) Kónyi Manó levelesládája. In Scheiber S. (szerk.) Évkönyv 1983/84. Magyar Izraeliták Országos Képviselete, Budapest. 310-318.

Sándor I. [1945] Író és társadalom. Fejezetek magyar felvilágosodás irodalomtörténetéből 1.: Főúr és nemes. Ráció, Budapest 2012.

Smelser, N. J. (1963) Theory of collective behavior. Glencoe Free Press, New York.

Spira Gy. (1974) 1848 nagyhete Pesten. Századok 2, 1974, 323-369. Elérhető: http://adt.arcanum.hu/index/a120107.htm?v=pdf\&a=p dfdata\&id=Szazadok_1974\&pg=168\&lang=hun\#pg=168\&zoom=f\&l=s (Letöltve: 2015-05-17)

Szabó D. (1989) Az elsodort falu [1919]. Csokonai, Debrecen. Elérhető: http://www.archive.org/stream/azelsodortfalure01szabuoft\#pa ge/186/mode/2up (Letöltve: 2015-05-17)

Szabó I. (é.n.) A magyarság életrajza [1941]. Magyar Történelmi Társulat, Budapest.

Szabó I. (2005) A magyar asszimiláció [1943]. In Erős V. Asszimiláció és retorika. Szabó István: A magyar asszimiláció című művének rekonstrukciója. Disputa, Debrecen, 11-74.

Szász L. (2014) „A háború után ...” A világháború utáni időszakra vonatkozó református tervek és koncepciók. In Baráth B. L. (szerk). Az I. világháború református tábori lelkészeire, tanáraira, diákjaira emlékezve. Tanulmányok. D. Dr. Harsányi Lajos Alapítvány, Debreceni Református Hittudományi Egyetem, Debrecen. 135-152.

Szekfü Gy. (1913) A számüzött Rákóczi 1715-1735. Magyar Tudományos Akadémia, Budapest. 
Szekfü Gy. (1920) Három nemzedék. Egy hanyatló kor története. Élet, Budapest.

Szekfü Gy. (1922a) Faji sajátosságaink a gazdaságtörténet világánál. Minerva 4-7, 8-10. 143-186, 270-304.

Szekfü Gy. (1922b) Három nemzedék. Egy hanyatló kor története. Élet, Budapest.

Szekfü Gy. (1923) [1917, 1922] A magyar állam életrajza. Történelmi tanulmány. Dick Manó, Budapest.

Szekfü Gy. (1934) Három nemzedék és ami utána következik. Királyi Magyar Egyetemi Nyomda, Budapest.

Szekfü Gy. (2002) [1922] A magyar bortermelö lelki alkata. Történelmi tanulmány. Mundus Magyar Egyetemi Kiadó, Budapest. 9-98. Elérhető: https://archive.org/details/magyarbortermell00szek (Letöltve: 2015-05-17)

Szociológiai Szemle (2010) 4. (A folyóirat tematikus száma Erdei Ferenc születésének centenáriumára).

Szőts Z. O. (2014) Mályusz Elemér és a népiségtörténet koncepciója. Újkor.hu 2014. Elérhető: http://ujkor.hu/portre/malyusz_elemer (Letöltve: 2015-05-17).

Takáts J. (1996) Kállay Béni, John Stuart Mill és a modern társadalom. Holmi 5, 774-779. Elérhető: http://holmi.org/pdf/archive/ holmi1996-05.pdf (Letöltve: 2015-05-17)

Ungár L. (é.n.) Kapitalisztikus gazdálkodás [1943]. In Miskolczy Gy. (szerk.) Az új Magyarország. Domanovszky Sándor (szerk.) Ma-gyar Müvelödéstörténet 5. Magyar Történelmi Társulat, h.n. 201-236. Elérhető: http://mek.oszk.hu/09100/09175/html/79.html (Letöltve: 2015-05-17)

Ungár L. (1935) A magyar nemesi birtok eladósodása 1848 előtt. Századok 1-3, 1935, 39-60. Elérhető: http://adt.arcanum.hu/index/ a120107.htm?v=pdf\&a=pdfdata\&id=Szazadok_1935\&pg=24\&lang=hun\#pg=24\&zoom=f\&l=s (Letöltve: 2015-05-17)

Ungár L. (1938) A hazai céhrendszer bomlásáról. Századok 4-6, 167-191. Elérhető: http://adt.arcanum.hu/index/a120107.htm?v=pdf \&a=pdfdata\&id=Szazadok_1938\&pg=90\&lang=hun\#pg=90\&zoom=f\&l=s (Letöltve: 2015-05-17)

Ungár L. (1942) Szempontok a magyar polgári osztály kialakulásának vizsgálatához. Századok 7-8, 306-328. Elérhető: http://adt. arcanum.hu/index/a120107.htm?v=pdf\&a=pdfdata\&id=Szazadok_1942\&pg=157\&lang=hun\#pg=157\&zoom=f\&l=s (Letöltve: 2015-05-17) 